\title{
THE PRO-CARTHAGINIAN AND PRO-ROMAN HISPANORVM COIN ISSUES OF SiCILY (214-210 BC)
}

\author{
Fernando López SÁNCHEZ
}

Universitat Jaume I / Wolfson College/Oxford

Recibido: 14-10-2013 | Evaluado: 28-11-2013 | Aprobado: 28-11-2013

RESUMEN: Las series monetales sicilianas con leyenda HISPANORVM no se acuñaron únicamente tras la caída de Siracusa a finales del año 212 a. C. ${ }^{1}$ No tuvieron tampoco una filiación exclusivamente romana. La mitad de las emisiones HISPANORVM presenta unas tipologías y unas facturas que deben vincularse con la $\mathrm{V}$ democracia siracusana -pro-cartaginesa- de Epícides e Hipócrates (214-212). Las monedas HISPANORVM fueron acuñadas en las cecas de Leontini, Siracusa, Mesina y Agrigento por grabadores no hispanos y nunca en grandes cantidades. Fueron fabricadas para ser entregadas a una cohors hispanorvm de 300, o, más probablemente, de 600 hispanos y númidas, la cual se convirtió en guardia de corps de Epícides e Hipócrates. Marcelo y Laevino utilizaron a esta cohorte hispánica en su beneficio durante los años 211 y 210 , y en casi todas las áreas geográficas sicilianas anteriormente útiles a Cartago. Los hispani que se instalaron en Morgantina lo hicieron probablemente no antes de la pacificación de Sicilia en el año 210.

Palabras clave: auxiliares, cohorte, hispani, mamertinos, mercenarios, pro-cartaginés, pro-romano, series monetales, Siracusa.

AbStract: The Sicilian coin issues with the legend Hispanorvm were not only coined after the fall of Syracuse late in the year $212 \mathrm{BC},{ }^{2}$ and neither were they of exclusively Roman pedigree. Half of the HISPANORVM issues display a typology and manufacture that must be

1. Todas las fechas son a. C.

2. All dates are before Christ (BC) 
linked with the fifth Syracusan (and pro-Carthaginian) democracy of Epicydes and Hippocrates (214-212). HISPANORVM coins were minted at Leontini, Syracuse, Messana and Agrigentum by non-Hispanic engravers, and never in large quantities. They were made for delivery to a HISPANORVM military unit of 300, or, more plausibly, 600 Hispanic and Numidian troops who became the personal guard of Epicydes and Hippocrates. In the years 211 and 210, Marcellus and Laevinus used this Hispanic unit for their own purposes in almost all of the Sicilian locations which had previously served Carthage, while the hispani who settled in Morgantina, on the other hand, probably did not do so until the pacification of Sicily in 210.

Keywords: Auxiliaries, cohort, coin issues, hispani, mamertines, mercenaries, pro-Carthaginian, pro-Roman, Syracuse.

\title{
Hispani And mamertini in Sicily during the Second Punic War: Were
} THEY ONLY THERE AFTER 212, AND WERE THEY SOLELY PRO-ROMAN?

\begin{abstract}
A
s Vico points out, considerable interest has been shown by numismatists, archaeologists and historians in the Sicilian coin issues with the legend HISPANORVM, ever since Paruta began to catalogue them in $1612 .{ }^{3}$ In recent decades this interest has been revived, and there has been some remarkable progress in our understanding of them. From a strictly numismatic standpoint, five series and nine issues have so far been differentiated, with notable variety in both types and style. ${ }^{4}$ From an archaeological perspective, the finding of 198 bronze coins with the legend HISPANORVM in the excavations conducted at Morgantina by the University of Princeton (USA) in the years 19567 (Serra Orlando, Aidone) $-6 \%$ of the total of 3261 found $-{ }^{5}$ has led to the identification of this city as the mint of all these Sicilian issues. Finally, the textual information provided by Livy (26. 21. 9-17) regarding the posting of a contingent of Hispanic veterans in the same city of Morgantina in the year 211 («ex iis Murgentiam Hispanis quibus urbs agerque debebatur ex senatus consulto attribuit») has established that the coins must have been minted

3. Vico Belmonte, A., «Las monedas sicilianas con leyenda Hispanorvm. Un estado de la cuestión», 56 (250), 2006, 346; Maringo, G. B. (ed.), Della Sicilia di Filippo Paruta : descritta con medaglie, Palermo, 1612.

4. Vico Belmonte, «Las monedas sicilianas», 353-356. See also Amela Valverde, L., «La emisión HISPANORVM de Morgatina», Omni, 7 (numerical version), 2013, 34-44.

5. Erim, K. T., The «Hispanorvm» Coins: Problems in Sicilian Numismatics and History, Princeton, Diss. Princeton University, Priceton, 1957, viii; See also Buttrey, T. V. \& Erim, K. T. \& Groves T. D. \& Holloway, R. R., Morgantina Studies II, The Coins, Princeton. Princeton University Press, 1989, 3-34.
\end{abstract}


shortly after this date, ${ }^{6}$ leading to the discounting of much later chronologies for these series, such as those suggested by the excavators of Serra Orlando themselves (after $150 \mathrm{BC}){ }^{7}$ or Heiss $(43 \mathrm{BC}){ }^{8}$

However, despite all the aforementioned progress, there are several aspects of the HISPANORVM coin series that have not yet been explored, either by historians or by numismatists. Firstly, the hispani soldiers are mentioned by Livy in the context of the Second Punic War in Sicily, before the years 212 and 211. Immediately after the death of King Hieronymus of Syracuse at Leontini in the year 214, the historian identifies a contingent of Spaniards and Numidians as auxiliary Carthaginian troops -rather than «mercenaries»- acting on behalf of the Hannibal's envoys, Epicydes and Hippocrates and against the previous political order («African and Spanish auxiliaries had been made ready for the slaughter of the magistrates and other leading citizens», Livy 24.24.5). ${ }^{9}$ Secondly, and from a strictly numismatic perspective, the very variaribility of the HISPANORVM coin series, too, invites us to believe that they were minted for use well before the end of the Sicilian war in the year 210. They display numerous similarities with a number of Bruttian, Syracusan and Mamertine coins from the period of the Second Punic War, and it is also recognised that many of these series which are very similar to some HISPANORVM types were minted before the year 212. According to the information provided by Livy, there is no reason why the HISPANORVM coin issues in Sicily should be linked exclusively either with services to Rome provided by the hispani or with the city of Morgantina. Bronze coinage with military connotations was used in the Hellenistic world above all within active military garrisons rather than in camps for discharged veterans, ${ }^{10}$ and in this case the sheer variety of the

6. Caccamo Caltabiano, M., «Sulla cronologia e la metrología delle serie Hispanorvm», QTNAC (Quaderni Ticinesi: Numismatica e antiquitá classiche), 14, 1985, 159-169, based on the similarity between the type of the horseman in the series with the legend HISPANORVM and the one shown on the coins of Hiero II, who died in 215; BeLtrán LlORIS, F., «...'Et sola omnium provinciarum uires suas postquam uictaest intellexit'. Una aproximación a Hispania como referente identitario en el mundo romano", Caballos Rufino, A \& Lefebvre, S. (eds.) Roma generadora de indentidades: la experiencia hispana, Madrid, Casa de Velázquez-Universidad de Sevilla, 2011, 67 and note 53; Carrocio, B., Dal basileus Agatocle a Roma: le monetazionie siciliane d'età ellenistica : cronologia, iconografia, metrología, Messana, Di.Sc.A.M, 2004, 60-61 for the chronological estimates of various numismatists, on the HISPANORVM coin series, all after the year 211 .

7. ERim, Morgantina Studies II, 36-39; Beltrán Lloris, «...Et sola omnium provinciarum», 67 and note 52.

8. Heiss, A., «Notes sur les monnaies de bronze avec la légende 'HISPANORVM'», Annuaire de la Société française de numismatique et d'archéologie, tome III (1868), première partie, 278-281; ERIM, The «Hispanorvm» Coins, vii, viii, xi.

9. See also 21. 4-12. Livy links the Spaniards with the recently-arrived Epicydes and Hippocrates on the orders of Hannibal («and ambassadors were sent to Hannibal, and he sent back with a young noble named Hannibal also Hippocrates and Epicydes (...) Through these men an alliance was made between Hannibal and the tyrant of Syracuse», Livy 24.6.2-9).

10. The utilitarian and military nature of the bronze coinage found in camps and cities is a salient characteristic, as De Callatä̈, F., «Coins and Archaeology: the (Mis)use of Mithirdatic Coins for Chronological Purposes in the Bosporan Area», in Stolba, V. \& Hannestad, L. (eds.) Chronologies of the Black Sea Area in the Period c. 400-100 BC, Aarhus, Black Sea Studies 3, Aarhus University Press, 2005, 136, points out with regard to the reasons for minting «civic» bronze series in a number of cities of the Aegean and Black Seas from the third to the first century; See also PUGLISI, M., «Coin circulation data as a source 
HISPANORVM issues suggests that they were minted for use before the end of the Sicilian war in 210.

As far as Mamertine coinage, perhaps the most similar to the HISPANORVM coin issues, is concerned, it is true that a historian as specialised in Italian mercenaries as Tagliamonte has gone so far as to state that «the case of the Mamertines is to be excluded from the mercenary scene in Sicily during the Second Punic War as in many ways it represents a relic of the past» ${ }^{11}$. It is also true that there exists a certain scepticism among some numismatists as regards chronological links between certain Mamertine series and Bruttian and proCarthaginian models from before the year 212. This is, for example, the opinion of Carollo \& Morello, who affirm that «when Syracuse joined the Carthaginians the war struck Sicily with all its devastating force and the Mamertines became protagonists once more, on the side of the Romans». ${ }^{12}$ However, the doubts that have been expressed regarding the chronology of the Mamertine coinage since the publication of the seminal Sämstrom catalogue in 1941, suggest that the MAMEPTIN $\omega N$ coin issues, as the HiSPANORVM series, may have been minted from the year 214 onwards, and not only from the year 211/210. Sämstrom states in this regard that Mamertine coinage in Sicily seems to have begun to be minted «during the time of Hyeronimus and the Syracusan Republic (215-214)», ${ }^{13}$ and was most likely neither linked with Rome nor with periods following the fall of Syracuse (autumn 212). Sämstrom also points out that the technique used in the preparation of the blanks and the thickness and the relief of the Mamertine, Syracusan, Bruttian and Reghium coins clearly show that two different set of coins were produced: the oldest and most refined coinciding with the first phase of the Second Punic War in Sicily [Fig. 1], and the second one, coarser in technique, contemporary with the phase in which Rome came to power on the island [Fig. 2]. The differences in style and workmanship between these two successive stages of Mamertine coin production in Sicily are so obvious that they even affect the orientation of the busts, because, as is noted by Sämström, "whereas in Series XI and XII the head on the (Mamertine) obverse is turned to the left, as in Syracusan coins during the reign of Hiero and in the Rhegian coins (...), the head on the obverse of all subsequent Mamertine coins is turned to the right as in the Roman-Sicilian bronze coins». ${ }^{14}$ These observations, although not fully exploited in further studies, have nevertheless been accepted by Carollo \& Morello in 1999. In this work, the authors recognise that there was a second phase of monetary production during the Second Punic War where

for quantifying monetary supplies», in DE CALlatä̈ (ed.), Quantifying Monetary Supplies in Greco-Roman Times, Bari, Edipuglia, 2011, 190-193.

11. Tagliamonte, G., «I figli di Marte. Mobilità. Mercenari e mercenariato italici in Magna Grecia e Sicilia», Tyrrhenica. Studi archeologici sull'Italia antica collana directa da Giovanni Colonna III. Roma, Archeologica 105, 1994, 213.

12. Carollo S. \& Morello, A., Mamertini. Storia e monetazione, Nummus et Historia III, Formia. Circolo Numismatico Mario Rasile, 1999, 129.

13. S̈̈rström, M., A study in the coinage of the Mamertines, Lund. C. W. K. Gleerup, 1940, 33.

14. Idem. 


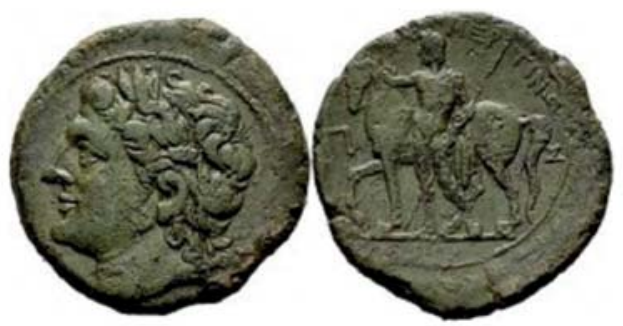

Fig. 1. mameptinwn, Bronze, Pentonkion, 10.43 g. Before 212, Bust of Ares 1. / Cavalryman with spear near horse, Dr. Busso Peus Nachfolge, Auction 409 (25.04.2013), Lot number 42

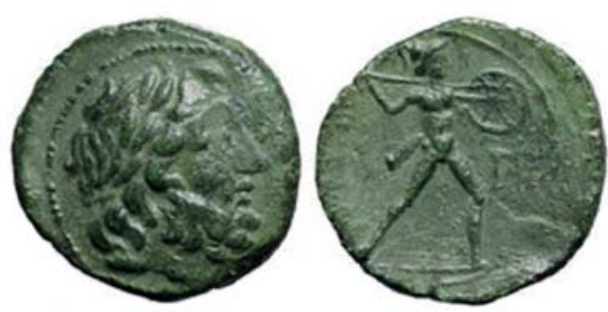

Fig. 2. Mameptin $\omega$ N, Bronze, Pentonkion around 210. Bust of wreathed Zeus r. / Naked warrior $r$. with shield and spear. Roma Numismatics Limited, E-Sa le 5 (08.02.2014), Lot number 134

«on the whole the coins seems to have made by an Italian artist and not by Greco-Sicilian engravers... as a result, for their own money the Mamertines must have resorted to an artist who was less refined in technique but equally expressive»..$^{15}$

The HISPANORVM series exhibit each and every one of the typical characteristics of the two subsets of Mamertine coinage catalogued in Sämstrom's «Period IV» (220-200 BC). The first subset is made up of coins of superior style and manufacture with busts facing to the left, except in one case. ${ }^{16}$ In addition, the types chosen by the engravers for these issues may be related to the very recording of the fifth Syracusan democracy (head of Athena with helmet) or the first coin issue of the Bruttian koinon in Calabria (Artemis). Moreover, a second subset of coins with the legend HISPANORVM is characterised by smaller and thicker coins, with more pronounced relief on the figures. The style is now cruder and of lower quality than in the first subset, a sure sign that these coin engravers were not so experienced. The busts on all these coins face right and show either a mature Zeus, bearded and laureate (which follows, again, the pattern set by Bruttian coins of a later period), or a juvenile male bust, laureate or not.

15. Ibidem, 130.

16. The eight issue of the fifth Hispanorvm series of Vico, see below, Fig. 3. 
HISPANORVM coins are not as abundant in Sicily as Bruttian, Syracusan or Mamertine ones. The information that may be extracted from archaeological contexts -apart from that provided by Morgantina/Serra Orlando, Aidone- ${ }^{17}$ or from hoards and occasional findings must necessarily be limited. However, the texts of Livy and numismatic logic alone are sufficient to undertake a substantial redefinition of our understanding of the HISPANORVM coin issues. The following pages aim to study the different types of these Sicilian series from a comparative perspective, and also attempt to reveal the ultimate authority (or authorities) behind the production of these coins, as well as the different mints involved. The objective is above all to understand the importance of and the changes in the Hispanic contingent in Sicily during the Second Punic War.

The hispani at Leontini: in support of Carthage (214) And Rome $(211 / 210)$

It is significant that the onset of Syracusan stasis, and indeed the entire Sicilian phase of the Second Punic War (214-210), should have taken place at Leontini, where King Hieronymus was assassinated at the beginning of the summer of 214 (Livy 24. 4-7.9). According to Livy (24.21.1 ss), the motivations of the murderers were to remove the monarchy and so establish the fifth Syracusan democracy in the hands of Adranodoros and certain other conspirators $^{18}$. The young democracy's attempt to curry favour with Rome by sending two embassies, one to Appius Claudius Pulcher, still propraetor in western Sicily (РоLYв. 8.3.1), and another to Marcellus, who had quickly arrived in Sicily from Nola (Livy 24.27.6), did not go down well with the proCarthaginian faction in Syracuse. Shortly after coming to power, Adranodoros and other members of his circle were therefore accused by the pro-Punic faction in Syracuse, led by Epicydes and Hippocrates, of conspiring to restore the monarchy, and they were soon murdered amid scenes of extreme barbarity.

When Appius Claudius Pulcher sent his warships to the port of Syracuse in response to the invitation of the now-dead Adranodoros, a large part of the Syracusan population, spurred on by Hippocrates and Epicydes, rose up in opposition. Another pro-Roman voice, Apollonides, after pacifying the anti-Roman masses stirred up by Hippocrates and Epicydes, did manage to send an embassy to Rome ratifying the new Syracusan-Roman alliance (Livy 24.27.7). When the Roman army was close to the town, «ambassadors from Leontini arrived, pleading for a force to defend their territory. The request of this seemed very timely for the purpose of relieving the city of a disorderly and

17. ERIM, The «Hispanorvm» Coins, viii-ix provides the following list of coins found in the Morgantina excavations: 132 Athena head l. /horseman charging r.; 45 Male head l. /horseman charging r.; 9 bearded head r. /Pegasus flying r.; 4 female head l. wearing diadem /Victory standing l; 4 Athena head r. /apex; 1 young male laureate head r. /apex; 1 bearded head l. /Eagle with serpent.

18. Lazenby, J. F., The First Punic War. A Military History, London and New York. Routledge, 1996, 103. 
turbulent multitude and of sending away its leaders» (Livy 24.28.1). The royal treasure had been moved to Leontini from Syracuse (Map 1) before the murder of King Hieronymus, and this seems to suggest that the city had a dependent status with respect to Syracuse during this period (Livy 24. 22. 14-23). For this reason, Livy reports that «Hippocrates, as magistrate, was ordered to go to Leontini», accompanied by «4,000 armed men», fundamentally «deserters», adding that «many of the mercenary auxiliaries followed». Marcellus, deeply concerned about the movements of Hippocrates, who had already begun to mount a series of raids, ravaging areas on the borders of the Roman province in Sicily (214 BC), then declared war on him, also calling on Apollonides to expel Epicydes from the town. The departure from Syracuse of Epicydes, following his brother, can be seen as a triumph for the pressure exerted by Marcellus, though it also caused the breakdown of relations between Apollonides and the two agents of Hannibal on the proclamation of the independence of Leontini.

In my opinion, the eight issue of the HISPANORVM fifth series of Vico should be attributed to Leontini, and equally it must be assumed that it was minted at the same time as the above events. On the obverse, there is a helmeted bust of Athena on the right as a sign of civic obedience to the Syracusan authorities, ${ }^{19}$ and on the reverse there is an apex, which has warlike

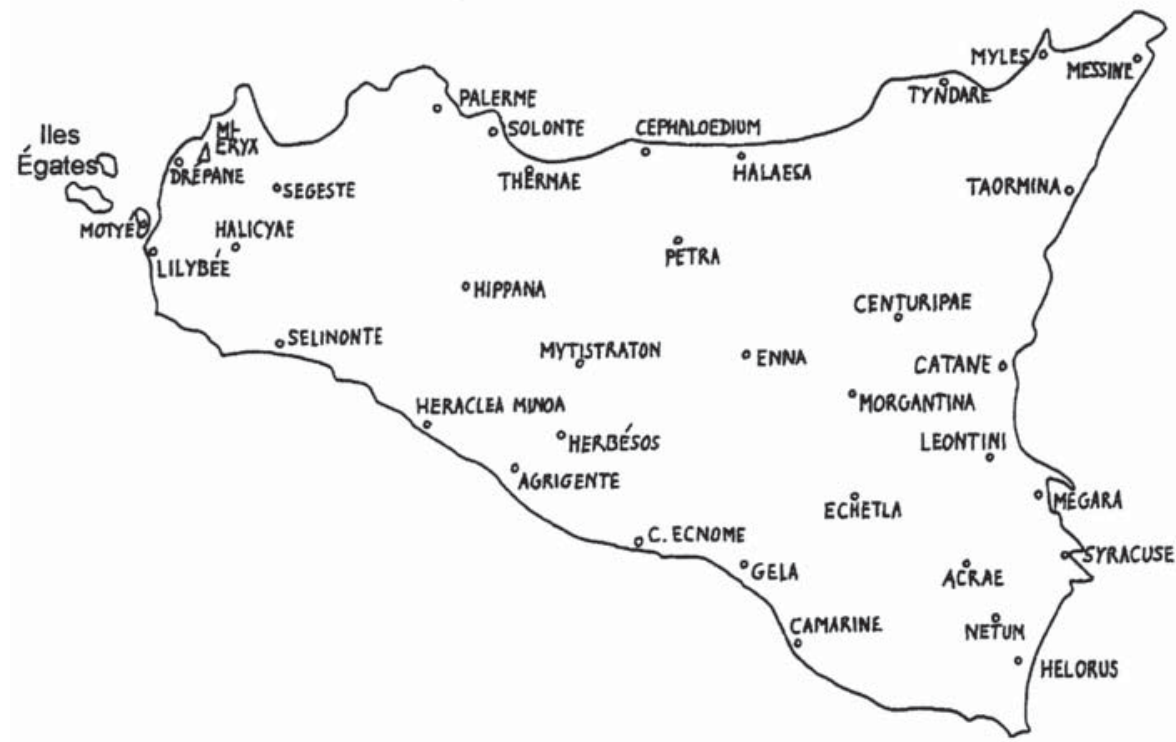

Map 1. Cities of Sicily during the 3rd century BC. Le BoheC, Y., 1996, 64, pl. 11

19. As Rutter, N. K. et al, Historia Numorum. Italy, (HNI), London, The British Museum Press, 2001, 45, point out, it is true that the head of Athena with a helmet is common in the south of Italy, from Caelia as far as other Apulian mints such as Azetium, Hyria, Luceria, Rubi, Teate, Venusia and Vibo Valentia. The style of this Athena is, however, unmistakeably Syracusan, and along with the legend HISPANORVM, it is only possible to attribute this issue to Syracuse. 
connotations in the Italic world [Fig. 3]. This is, besides, a HISPANORVM type of great style and high-quality manufacture which can only be related to the styles and manufactures typical of Sicilian and Italian coin issues from before the

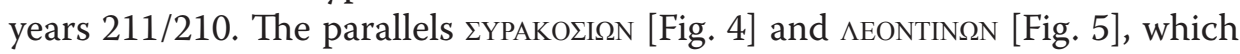
show a wreathed bust of Apollo to the left on the obverse, may be considered in chronological terms to be attributable to the end of the third century, and it is most probable that they should be assigned to a very early phase of the Second Punic War in Sicily. Given that the town of Leontini was in the possession of Syracuse during the Second Punic War, it may be deduced that the type with

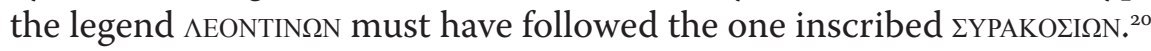
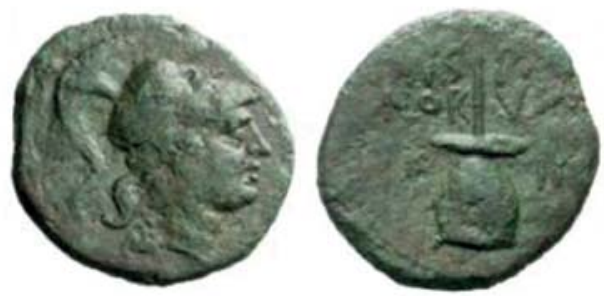

Fig. 3. Hispanorvm, Bronze, 214, 3.17 g, d. 20 mm; Helmeted bust of Athena r./ Apex, Numismatica Ars Classica, Auction, Auction date: 12 May 2005, Lot number: 1201

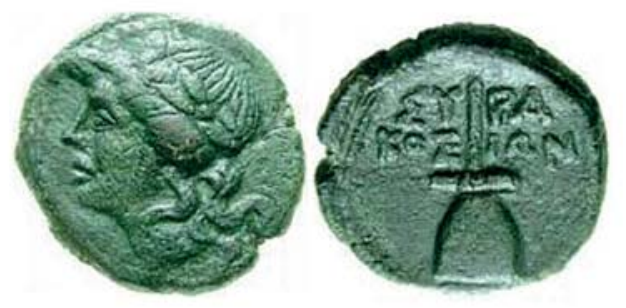

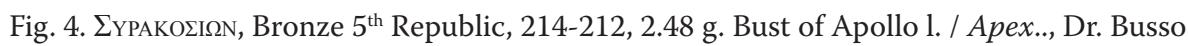
Peus Nachfolger, Auction 371, Auction date: 24 April 2002. Lot number: 85

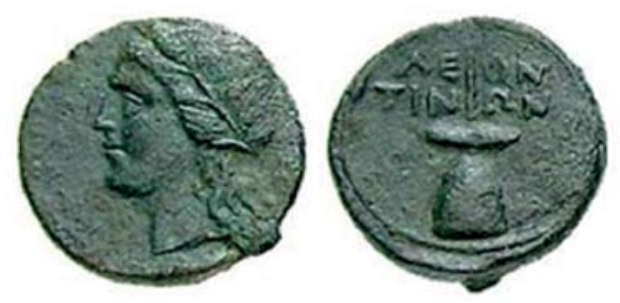

Fig. 5. $\Lambda$ EONTIN $\Omega$, Bronze Wreathed bust of Apollo l./ Apex Classical Numismatic Group, Mail Bid Sale 61, Auction date: 25 September 2002, Lot number: 126

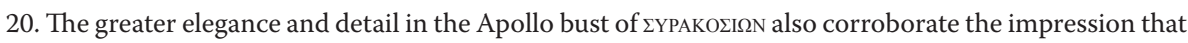
the $\Lambda$ EONTIN $\Omega N$ types were made by Syracusan engravers. 


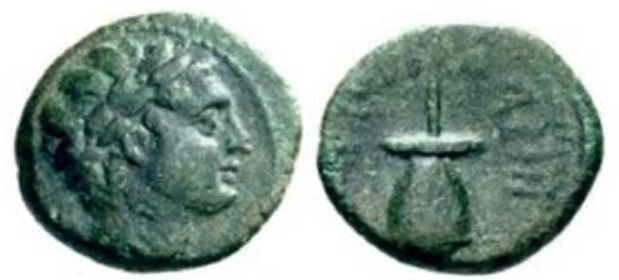

Fig. 6. HISPANORVM , Bronze, 211-210, 2.5. g. Wreathed head of Ares r. /Apex, AmELA VALVERDE, «La emisión HISPANORVM», 38, HGC 2917

If the war history of the Sicilian hispani is to be confined to the years 214210, and as Epicydes and Hippocrates established themselves in Leontini only

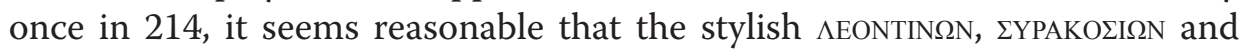
HISPANORVM coin issues should be assigned to the town of Leontini and to the year 214. They could all have been coined for the garrison of deserters and auxiliary mercenaries of Hippocrates, who settled in the town and then

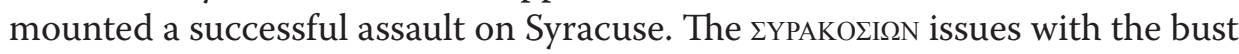
of Apollo could have been struck for (pro-Punic) Syracusan deserter forces before the independence of Leontini in late 214, and the $\Lambda$ EONTINSN series, too, must have been minted for this same deserter public, but this time after the proclamation of the independence of Leontini. The HISPANORVM issue with the bust of Athena, meanwhile, seems to indicate its connection to Syracuse, probably because the hispani of Epicydes and Hippocrates were considered closer to them, and therefore to Syracuse, than the deserter forces. The HISPANORVM coins with a juvenile bust on the right -more likely of Ares than of Apollo- ${ }^{21}$ [Fig. 6] must be considered to have been coined at another time, and the similarities with other coins with a bust on the right and similar manufacture make it logical to view it as the result of Roman influence, and from after the year 212 .

The hispani of Messana and Syracuse and the Pro-Carthaginian NíK $\alpha$ REVOLT (LATE 214)

The third issue of the first HISPANORVM coin series of Vico shows on the obverse a diademed bust of Artemisa on the left, with a quiver on her back and the letter «N» behind, and on the reverse a Nike (Victory), standing to the left holding a wreath in her right hand and a palm branch in her left [Fig. 7]. This reverse type is not without exact parallels, since, as Vico knowingly points out, a winged, standing Nike with a wreath «is a common motif (...) on the coins

21. VICO BeLMONTE, «Las monedas sicilianas», 356. 
of the south of Italy and Sicily, and indeed in Mamertine coins we can find an almost identical issue» ${ }^{22}$ [Fig. 8]. It is true that the Mamertine reverse types that Vico refers to are Carollo \& Morello nos. 1, 2, 3, and above all nos. 22, 23, 37 and 43, all minted in the city of Messana. The Mamertine series 22, 23 and 37 (and very possibly 43 too) all display a bust of Apollo on the obverse and are considered by Carollo \& Morello as having being minted between the years $215 / 214$ and $211 .{ }^{23}$ In this sense, the style of the bust of Apollo in series nos 22, 23 and 37 (and 43?) has notable parallels in style and manufacture with the coin issues of pro-Carthaginian Italy between the years 215 and $212 .{ }^{24}$ Nike as a monetary type meanwhile is widely used in the gold, silver and bronze coins of the Bruttian koinon, of known pro-Carthaginian sympathies during this period..$^{25}$

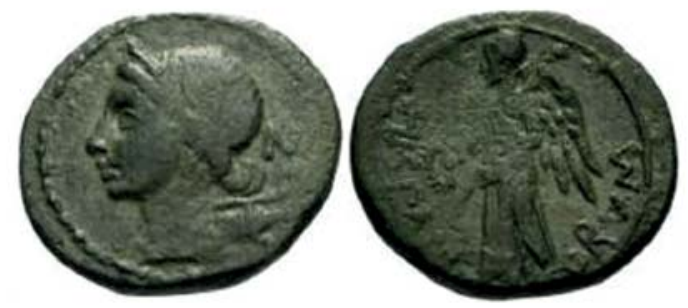

Fig. 7. Hispanorvm, Messana, Bronze, 214-213, 2.33 g, 14 mm, Bust of Artemisa l. /Nike standing l., holding wreath and palm-branch., Numismatica Ars Classica, Auction date: 13 May 2004, Lot number: 1358

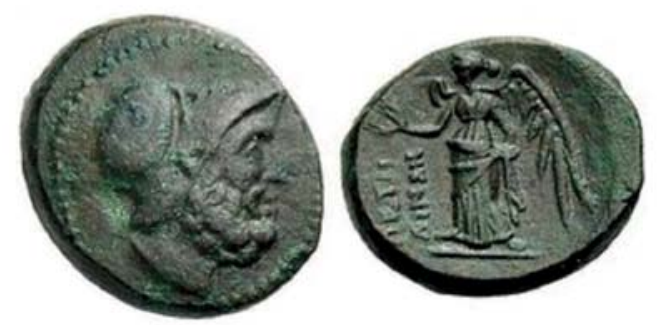

Fig. 8. Bruttium, Peth-Linw [N] (Petelia), Bronze Uncia, 216-204, 3.94 g. Bust of Ares r., wearing crested Corinthian helmet / Nike standing left, holding wreath in right hand, Münzen \& Medaillen GmbH, Auction 38, Lot 4

22. Vico Belmonte, «Las monedas sicilianas», 355, note 51 for issue seven of the fourth series, which bears this same reverse.

23. Carollo \& Morello Mamertini, 124-126 Although the authors believe that the value signs depicted on the reverses of these Sicilian coin series must have been inspired by the Romans, the opposite argument is also valid, namely that such a «Roman custom» did in fact demonstrate an adaptation of Sicilian customs.

24. Thomsen, R., Early Roman Coinage. A Study of the Chronology III. Synthesis II, Aarhuus. Nationalmuseets Skrifter. Arckæologisk-Historik Række X, 1961, 105; López SÁnCHEZ, F., «Numidian Kings and Numidian garrisons during the Second Punic War: Coins and History», Potestas, 3, $2010,27$.

25. Arslan, E., Monetazione aurea ed argentea dei Bretti, Milan, 1989, Glaux 4, 41-55, pl. X-XXI. 
As regards the Hispanic series with a bust of Artemis on the left, a quiver and the letter «N», it is reasonable to suppose that it was issued to commemorate, in the well-chosen words of Carollo \& Morello, «the possession (...) of the city of the straits» ${ }^{26}$ and similarly the establishment of the fifth Syracusan democracy (214-212). Rhegium, an Italian city that traditionally shared with Messana the supervision of the straits of Messina, remained pro-Roman throughout the Second Punic War. ${ }^{27}$ It is, however, known that a Mamertine invitation to Hiero II to garrison Messana was submitted by the authorities of the latter city long before the outbreak of the Second Punic War (Polyb. $10.1,11.4)$, and that a Syracusan force had actually occupied the acropolis of the city (DIOD. 21.13.7). Thiel's assumption that Hiero II had withdrawn from Messana on Hannibal's arrival in Italy is merely a hypothesis of the author, as there is no reference to it in Livy' narrative. ${ }^{28}$ Study of Livy (24.36. 4 ss) with regard to the strange movements of the Roman fleet of thirty quinqueremes, which in the year 213 docked at Panormus and then chose to move towards Syracuse via the west of Sicily ${ }^{29}$ rather than the much shorter route through the straits of Messina, ${ }^{30}$ suggests instead that Messana was not exactly proRoman at the time. ${ }^{31}$ Hannibal's march from near Capua towards Rhegium in 212 (Роцув. 9. 6-7) also appears to suggest that the latter was the only enemy city of Carthage in the region around the straits and Messana. Finally, the mere existence of issue seven of the fourth HISPANORVM series ${ }^{32}$ also points to Messana being a pro-Carthaginian city before the coining. This coin issue features on its obverse a crudely-made bust of Zeus Eleutherius on the right. It should, according to Carollo \& Morello, be attributed to «an Italian artist and not to Greco-Sicilian engravers». ${ }^{33}$ It should also be noted in this respect that in all likelihood this issue was produced, like many of this type and manufacture in Sicily, after the fall of Syracuse in late $212 .^{34}$

26. Carollo \& Morello, Mamertini, 92.

27. Lazenby, J. F., Hannibal's War. A military history of the Second Punic War, Warsminster. Aris \& Phillips Ltd, 1978, 65.

28. Walbank, F. W., A Historical Commentary on Polybius, 3 vols, Oxford. Clarendon Press.,1957, 1967, 1979, 57; Thiel, J. H., A History of Roman Sea-power before the Second Punic War, Amsterdan. North Holland Publishing Co., 1954, 146, note 258.

29. Lilybaeum, in the West of the island, was firmly held by the Romans, Rankov, B., «The Second Punic War at Sea», Cornell, T. Rankov, B. \& Sabin, E. (eds), The Second Punic War - A Reappraisal, BICS Supplement 67, London, University of London, 1996, 54.

30. Compare the ease with which the Romans had managed to cross the straits of Messina from Rhegium during the First Punic War with the lack of information regarding any control of the city by Rome during the Second Punic War before the fall of Syracuse. A pro-Roman Messana in 214 would have implied a fall of Syracuse well before autumn 212. See Lazenby, The First Punic War, 45-50; Sicipio, with 7000 volunteers, crossed the Messina straits in 205 with 20 quiqueremes and 10 quadriremes (Livy 28.45.21-46.1; Pliny, NH 16.192).

31. It is also strange that Marcellus should have received his fourth legion also in Panormus and not in Messana, Lazenby, Hannibal's War 108, Walbank, A Historical Commentary II, 77-78.

32. ViCO BELMONTE, «Las monedas sicilianas», 356.

33. Carollo \& Morello, Mamertini, 130.

34. The garrison of Messana may have been reconditioned in 209, as was the pro-Roman garrison of Rhegium and, made up partly of «Bruttian deserters» and partly by Sicilians sent to the city from Agathyrna 
It may thus be argued that, rather than alluding to military victories, the triumphal reverses of the Mamertine and Hispanic issues with a Nike figure proclaim the existence of separate Mamertine and Spanish garrisons in the city, as well as pointing to the opening of hostilities against enemy positions nearby (especially Rhegium). If there had been a real desire for military commemoration on the part of the Hispanic and Mamertine engravers who made these coins, they would have added different trophies to the figures of the Victories, as was the case in some contemporary Bruttian coinage, which show a helmeted bust of Ares on the left on the obverse and a Nike standing on the left, holding a palm and a crowning trophy to the left with a wreath on the reverse [Fig. 9]. ${ }^{35}$ As they did not do so, the Mamertine and Hispanic types should be interpreted only as signs of the stationing of troops in Messana, and not as a sign of military victory. Artemis, with or without a quiver is, on the other hand, a divinity that is associated in many coin series with well-fortified positions (i. e. Abydos in 301, [Fig. 15]), and it seems safe to assume that the Hispanic garrison, unlike the Mamertine one, may have been stationed on the acropolis of Messana since the year 214. It was sent there directly from Syracuse at the beginning of the fifth democracy, just as Hiero II had sent his troops there years before.

The proclamation of a state of war in the Spanish and Mamertine garrisons at Messana would be lacking substance if there were not also some triumphal parallels in Syracuse. The most immediate and conclusive one might well be the type with the «N» inscribed after the bust of Athena with helmet and crest which is depicted on the obverse of the first issue of the first HISPANORVM/ HISPAN $\Omega$ RVM coin series [Fig. 10]. As regards the significance of this «N», both

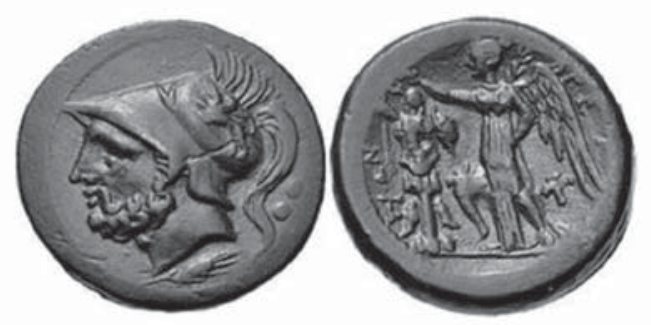

Fig. 9. BRUTtium, The Brettii, 214-211, Bronze, Didrachm or reduced sextans, $27 \mathrm{~mm}$, 17.94 g. Bust of Ares l., wearing helmet; grain ear below, two pellets behind / Nike standing l., erecting trophy; kerykeion between, plectron r.. Classical Numismatic Group, Electronic Auction 293, Auction date: 19 December 2012, Lot number: 6

(near Agrigentum), Livy 27.12.4, cf. 26.40.16-8, Polyb, 9.27.11), Lazenby, Hannibal's War, 175. The Spanish garrison may have left the city before this 209 .

35. HNI Italy 1975 (RUtTer, N. K. et al, Historia Numorum. Italy, 159, pl. 33) for bronze issues with this type; For a gold emidrachm with beardless head of Heracles and Victory crowning a trophy in Bruttian coinage, see ARSLAN, Monetazione aurea ed argentea, 71 and notes 193 and 194. 


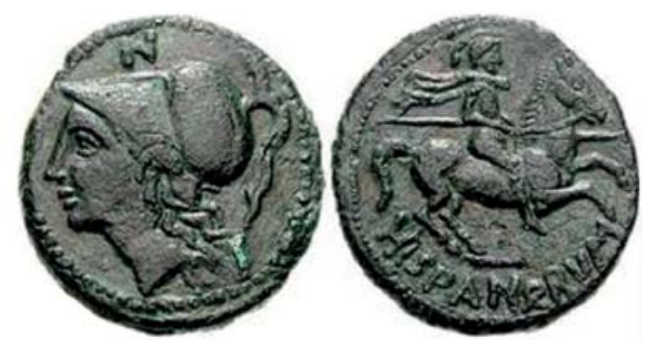

Fig. 10. Hispanorvm, Syracuse, 214-213, Bronze, 6.34 g. Helmeted bust of Athena l., $\mathrm{N}$ above / Warrior on horseback right, holding spear, Classical Numismatic Group, Mail Bid Sale 76, Auction date: 12 September 2007, Lot number: 136

in this issue and in the coin with the bust of Artemis, it cannot be considered to be a mark of value, as is recognised by Carrocio: «caution is essential, because the same letter $\mathrm{N}$ also appears in the Artemis/Nike series, perhaps too light for a half-uncial coin, even a small one». ${ }^{36}$ The same author also notes that «such an indication cannot be seen as a criterion for an uncia, which would have been too heavy», ${ }^{37}$ and that «it could therefore be inferred that it was in itself a unit of weight, divided into 12 calchoi and indicated with the letter $\mathrm{N}$, which could have been the first letter of its name. It is not, however, clear that this was nomos/nummus, a term which originally designated Sicilian silver». ${ }^{38}$ Value marks are also normally to be found on the reverses of Mamertine coins, and thus it might have been expected that the engravers of the HISPANORVM coin issues would also have inscribed them on the reverse, if that had indeed been their intention. Nor does it seem likely that the «N» on these coins may be interpreted as the initial of a magistrate, as has been suggested for the inscription $\Sigma \Omega$ in other series, which is said to refer to «Sosis», faber aerarius in Syracuse in the year 212 (LIVy 26.30.6). ${ }^{39}$ It is true that some of the coins of the fifth Syracusan democracy, especially some of the last issues of Hiero II and the first of Hieronymus, appear to share some of the same letters, and that these could be interpreted as the initials of the same magistrates, who served both monarchs. ${ }^{40}$ The «N» of the HISPANORVM issues does not, however, correspond to this phenomenon.

Once the metrological and civic hypotheses have been discarded, the most plausible explanation for the initial «N» in the issue with Artemis and Athena in Messana and Syracuse seems then to relate to a celebration of political affirmation on the part of the newly-elected Syracusan generals Hippocrates

36. Carrocio, Dal Basileus Agatocle. 114

37. Idem.

38. Idem

39. Carollo \& Morello, Mamertini, 74 and note 48; Holloway, R. R., The Thirteen-months coinage of Hyeronimus of Syracuse, Antike Münzen und geschnittene Steine, 3, Berlin de Gruyter, 1969.

40. Carrocio, Dal Basileus Agatocle. 114 
and Epicydes in the year 214 (confusaque haec omnis multitudo Hippocratem atque Epicydem creant praetores, Livy 24.32.4). Livy refers to «revolution» on three occasions when he narrates the takeover of these two agents of Hannibal in the wake of the assassination of the Syracusan king Hieronymus at Leontini (Livy 24. 7. 1-9). The climax of this process occurred when the agents of Hannibal managed to stir up on their behalf defectors, mercenaries and all kinds of people of low status in Syracuse, until the point when the old civic order was altered in their favour (slaves were called to wear the cap of freedom and criminals released from prison in chains and Syracuse, after the light of liberty had shone upon it for a short time, had fallen back into its oldtime servitude, Livy, 24.32. 9). Greek revolutionary movements of a populist and anti-monarchist bent, such as those described by Livy in the context of the Syracuse takeover, were traditionally viewed in the Greek-speaking world as campaigns involving violent agitation of the common people with military

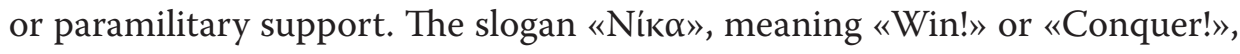
fitted in well in this changing political situation, changes that were conceived and executed as true military offensives. In this regard it seems relevant to note that, as late as 1 January 532, the rebellion in Constantinople narrated by Procopius, which almost cost Justinian I his throne and life, was also planned and brought to fruition under the slogan «Ník $\alpha »{ }^{41}$ The $« N »$ inscribed prominently on the obverses of HispanORVM first and third issues from Messana and Syracuse should therefore probably be considered as short for Ník $\alpha$, both of which would be strictly contemporary in their celebration of the takeover of the city by Epicydes and Hippocrates. The initiative of sending a garrison of Hispanic auxiliaries to Messana should be attributed to these two new generals, and it is their competition which may explain the visible Bruttian style adopted on Mamertine and Hispanic coin issues after this date.

Their conquest of total power in Syracuse and their position as commandersin-chief led to their surrounding themselves with a special guard. Syracuse was remarkable for its capacity to supply bodyguards to its tyrants and kings: Dionysus I, for example, had been allowed 600 men as bodyguards -called

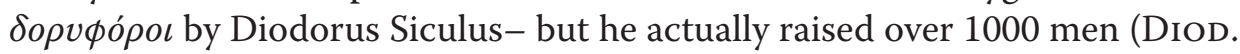
96.1; Arist. Pol. 1286 b 40). ${ }^{42}$ This guard had since the time of Dionysus preferably been stationed on the island of Ortigia or $v \tilde{\eta} \sigma o \varsigma$, near the individual to whom they owed their allegiance and whom they were employed to protect. ${ }^{43}$ In times closer to the fifth democracy, Hiero II had «personally selected a large number of new mercenaries who owed their loyalty directly to him rather

41. Procop. Pers. 1. 24. 40-42

42. PARKe, H. W., Greek mercenary Soldiers. From the earliest time to the battle of Pisus, Oxford. Clarendon Press, 1933, 65.

43. Xen. Hiero 6.5; PARKe, Greek mercenary Soldiers, 69. It is no coincidence in this respect that the prefect Moericus should have been in this position precisely at the time of his defection to Marcellus, or that Epicydes should have counterattacked from here with his guards when Marcellus himself entered Syracuse via the Hexapylon. See below. 


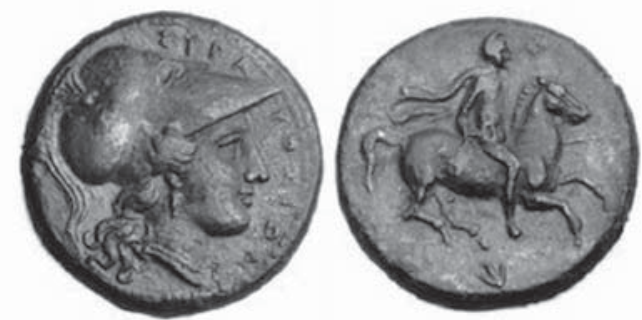

Fig. 11. ¿YpakozisN, Bronze, Syracuse. Agathocles (317-289). 20 mm, 6.99 g. Bust of Athena r. wearing crested Corinthian helmet pushed back on head / Cavalry rider on horseback r., cloak billowing behind; Heritage World Coin Auctions, Long Beach Signature Sale 3026, Auction date: 25 September 2013, Lot number: 23041

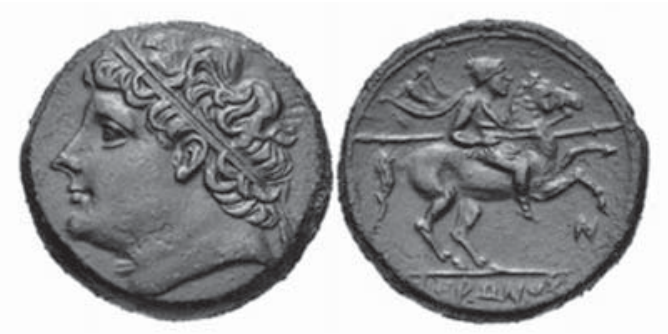

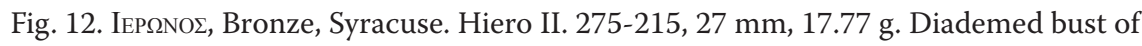
Hiero l. / Horseman riding right, holding spear; N below; Classical Numismatic Group, Electronic Group, Electronic Auction 260, Auction date: 20 July 2011, Lot number: 2

than the Syracusan state». ${ }^{44}$ It might be considered natural that Epicydes and

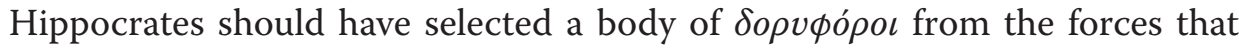
were available to them. The coin type with a crested Athena on the obverse does not, however, correspond exactly to that of Syracusan tyrants, but rather emphasises the civic values of the new Republic. It seems, then, that Epicydes and Hippocrates preferred to follow the model of Agathocles (317-289), who always refused to wear any kind of crown [Fig. 11] -on the contrary of Hiero II, the perfect example of a tyrant-king [Fig. 12]- and who considered his title of

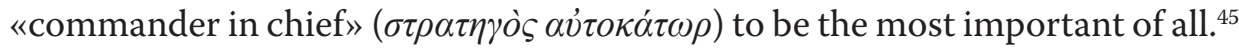
This does not mean, though, that the type of the lancer was a mere allegory in

44. Yalichev, S., Mercenaries of the Ancient World, London. Constable, 1997, 219.

45. Hippocrates and Epicydes had been born in Carthage of a Carthaginian mother, but his grandfather had been a prominent and exiled citizen of Syracuse (PoLy B 7.2.1-4; Livy 24.6.1-2). If this man is considered to have been Arcesilaus, first a friend and then an enemy of Agathocles (IUSTIN. 22.8.14), it was perhaps not mere chance that Hippocrates and Epicydes should have adopted the same horseman coin types as Agathocles did at the end of the fourth century. 
the series which adopted it. ${ }^{46}$ Although they did not have a formal bodyguard, Epicydes and Hippocrates do seem to have been in direct command of one unit above all others, and this was a hispanorvm unit, which served in effect as hispani corporis custodes, in the Syracuse fashion. ${ }^{47}$ Hellenistic monarchs used to choose foreign troops as corporis custodes units, ${ }^{48}$ and this is precisely the reason the Latin name HISPANORVM was adopted, ${ }^{49}$ to highlight the role of foreign bodyguard for the commanders in chief of Syracuse in 214. This was in spite of the fact that the engravers were Greek-speaking Syracusans, which can be seen not only in the types selected, but also in certain oversights in the legends, such as HISPAN $\Omega$ RVM (with $\Omega$, Fig. 10), or in the inscription of Greek letters such as $\Pi$ or $\mathrm{N}$ on the background of the obverse (see above and below).

The hispani DEFEND ACHRAdiNa (SPRING 212), With SOME FleEING With EPiCydes to Agrigentum (SUMmer 212). The HiSPANI OF ACHRADINA ALSO DEFECT TO ROME (AUTUMN 212)

The fourth coin issue of the second Hispanorvm series is very similar to the first issue of the first series. It represents on the obverse a helmeted head of Athena facing left, and, on the reverse, inside a dotted border, the usual legend HISPANORVM and a horseman in full armour galloping to the right, holding a spear. On the obverse of the fourth issue of the second series, however, the engravers preferred to reduce the size of the bust of Athena and introduce a ram's head above and to the left, as well as the Greek letter $\Pi$, in the lower part of the background to the left [Fig. 13]..$^{50}$ Carrocio notes in relation to this that «the $\Pi$, found on a large number of coin series of the time, would always have expressed a value of five unciae», and it is true that the letter $\Pi$ is inscribed on Mamertine pentokia as a clear sign of monetary value. However, it should be noted in this regard, as we have done before, that these indications of value are always placed on the reverse in Mamertine series [Fig. 1, 2], and never on the obverse. Besides, if the intention of the engravers

46. Carbè, A., «Il 'cavaliere' di Ierone II: aspetti iconografici», in Caccamo Caltabiano, M., Campagna, L. \& Pinzone, A. (ed.), Nuove prospettive della ricerca sulla Sicilia del III sec. a. C. Archeologia, Numismatica, Storia. Atti dell'Incontro di Studio (Messina 4-6 Iuglio 2002), Messina, Pelorias 11, 2004, 267-275, esp. 271-272.

47. Livy, 24.7.1-8 speaks of Dinomenes, one of the conspirators involved in the assassination of king Hieronymus in Leontini, as one of his custos corporis.

48. For the most famous corporis custodes of all, the Germani corporis custodes of the Julio-Claudians and Trajan, see Speidel, M. P., Riding for Caesar: the Roman Emperors' Horse Guards. B. T. Batsford Ltd., London, 1994, 15-40 and also López Sánchez, F. \& Hollard, D., «Les troupes germaniques des JulioClaudiens: un témoignage numismatique sur l'accession de Claude», Hollard (ed.) L'armée et la Monnaie. II. Actes de la journée d'études du 25 avril 2009 à la Monnaie de Paris. Recherches et Travaux de la Société d'Études Numismatiques et Archéologiques (SÉNA), n. ${ }^{\circ}$ 3, Paris, 2010, 43-66 and pl. IV-V.

49. BeLtrán Lloris, «Et sola omnium provinciarum», 67.

50. ERIM, The «Hispanorvm» Coins, viii, does not individualize this type in his study, no doubt because he considers it a variant of the main type of Athena head l./horseman charging $\mathrm{r}$. 


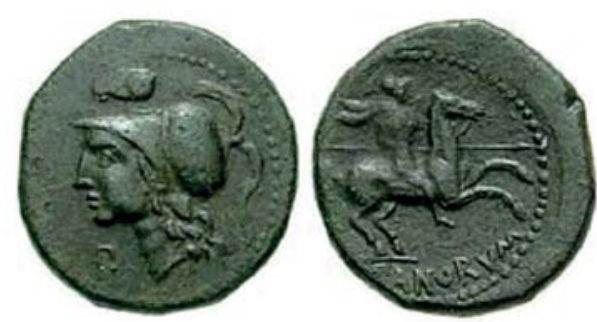

Fig. 13. HISPANORVM, 212 , Bronze, $21 \mathrm{~mm}, 6.52 \mathrm{~g}$. Helmeted bust of Athena l., ram's head above / Helmeted horseman right, Classical Numismatic Group, Mail Bid Sale 61, Auction date: 25 September 2002, Lot number: 119

had been to indicate that the value of these Hispanorvm bronzes was five uncias, it remains to be clarified why it was engraved only on the fourth issue of the second series and not on the first issue of the first series, which was of a similar diameter and weight.

Just as the «N»s inscribed on the first Hispanorvm issues of Messana and Syracuse appear to have explanatory value as far as the political situation of the time (214) is concerned, the same may also be the case as regards the significance of the letter $\Pi$ as found in the second issue of Vico. The battering ram as a symbol associated with the defence of a city appears on various Hellenistic coin issues, such as, for example, coinage referring to the town of Abydos round the year $301 / 300$, or shortly thereafter. The silver tetradrachm with the head of a young Heracles to the right in a lion-skin headdress, on

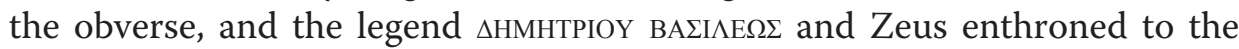
left, holding an eagle on an extended right hand and a sceptre to the left, on the reverse, also depicts a ram's head in the background to the left [Fig. 14]. ${ }^{51}$ As regards the ram's head on this coin, Newell notes that at the probable time of issue Demetrius Poliorcetes (306-283/2, king of Macedon between 294/3 and 288), was mustering his fleet at Chersonesus in Thrace in order to campaign against Lysimachus. As a source, Newell duly proposed a mint in the general region of the Propontis, specifically naming Abydos, a possession of Demetrius. Lysimachus besieged Abydos, but Demetrius relieved the city by sea and Lysimachus then withdrew (DiOD., 20.107.2-3). The battering ram on this silver coin seems therefore to refer to Lysimachus' attempt to take the town of Abydos, and the existence of bronze coins of $23 \mathrm{~mm}$ in diameter and about 8 grams in weight with a turreted head of Artemis to the right and a bow and quiver under his chin, on the obverse, and an eagle standing to the right on a thunderbolt, head turned to the left with a ram's head in front and the legend

51. Newell, E. T., The coinages of Demetrius Poliorcetes, London \& Oxford University Press. H. Milford, 1927, 64, pl. vi, 13. 


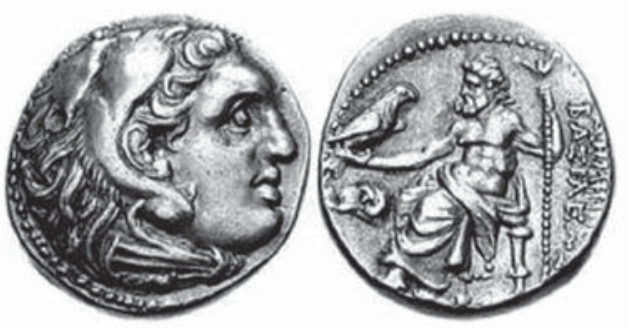

Fig. 14. Demetrios I Poliorketes. 306-283, Silver, Drachm, 4.28 g. Abydos. Struck circa 301-295. Head of Herakles right, wearing lion skin/ DHMHт[PIOU] BASILE $\Omega$, Zeus Aëtophoros seated 1.; in left field, ram's head left above monogram; Classical Numismatic Group, Triton X, Auction date: 9 January 2007, Lot number: 162
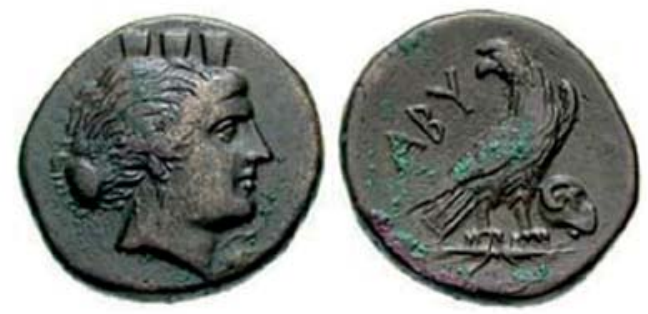

Fig. 15. Troas, Abydos. 300-250, Bronze, 23 mm, 8.07 g. Turreted head of Artemis right, bow and quiver under chin / Eagle standing r. on thunderbolt, head turned l.; ram's head before; Classical Numismatic Group, Mail Bid Sale 61, Auction date: 25 September 2002, Lot number: 263

$\mathrm{ABY}(\triangle \mathrm{O} \Sigma)$ on the reverse, also appear to suggest that the town of Abydos, and not only the king Lysimachus, left a record of the siege in the year 301 [Fig. $15] .^{52}$

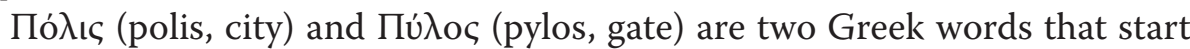
with $\Pi$ and which fit in well with the message that the engraver may have wished to convey in the fourth issue of the second HISPANORVM series, closely connected with the battering ram depicted on it. It seems reasonable to assume that the Greek letter $\Pi$ refers to one of these two terms, perhaps more

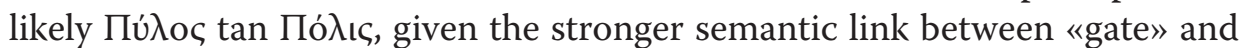
«ram's head». It is, however, hard to know which gate the currency in question was referring to. The Hexapylon (or Hexapyloi), certainly located at the Scala Graeca (Map. 2), formed part of the wall built by Dionysus I along the northern edge of the Epipolae, the plateau overlooking Syracuse, which was certainly attacked both during the Nika revolt by Epicydes and by Hippocrates in 214

52. Wroth, W, A Catalog of the Greek Coins in the British Museum (=BMC), Troas, Aeolis and Lesbos, London, The British Museum, 1894, 4, 37. 
(Livy, 24.32), ${ }^{53}$ as well as by Marcellus and his picked thousand men in the spring of $212 .{ }^{54}$ However, the Hexapylon or Hexapyloi, as its name indicates, seems to have been a succession of six gates, similar in every respect to the Trypylon (or set of three gates), once the western entrance to the Epipolai, just north of Euryalus..$^{55}$ The Hexapylon, important as it was, only allowed Marcellus to control the Epipolai plateau (Livy, 25.24. 1-7), and not the city of Syracuse itself, which had to be taken through negotiation. There is also no evidence to support the hypothesis that the hispani stationed in Syracuse had been in charge of the defence of the Hexapylon, as the fort of Euryalus, i. e., was under the command of Philodemus the Argive and his men (Livy, 24.25.2).

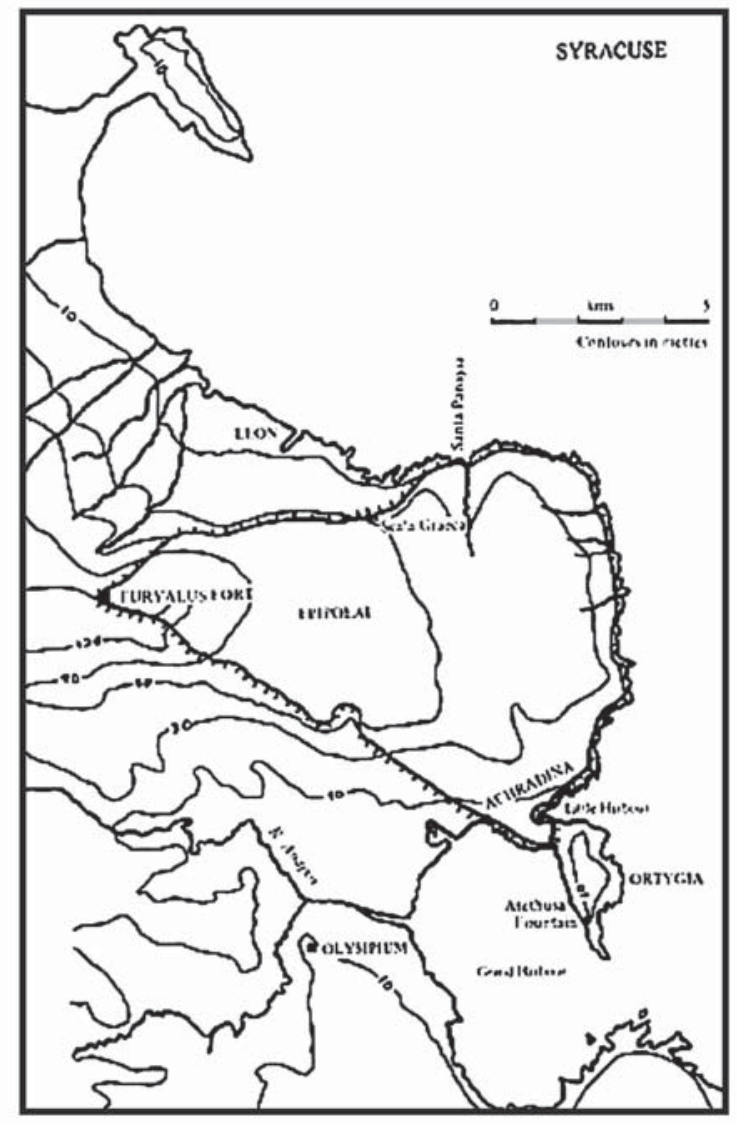

Map 2. Syracuse in 214-212, LAZENBy, Hannibal's War, Map 11

53. «By this time one of the gates of the Hexapylon had been opened, and by it they had begun to be admitted (...) and the gates were being forced with no less violence from within than from without, and when all had been forced, the column was admitted through the whole breadth of the Hexapylon (...) Thus Achradina also is taken by assault».

54. Livy, 24.39.12, РоLYB, 8.7.6.

55. Walbank, A Historical Commentary II, 70. 
When he found out about Marcellus' appearance on the plateau of Epipolai, Epicydes, who had remained on his own in Syracuse when Hippocrates had set out to meet Himilco (Livy, 24.35.4), «came out from the island, which they themselves call Nasos, with a quickly moving column» (Livy, 25.24 8-10), though he then withdrew into the Achradina quarter, which was shut off from the outer city by its own fortifications. Livy does not specify the composition of the «quickly moving column» advancing from Ortygia to Achradina, but given that the elite troops of Syracuse's generals and tyrants were normally stationed at Nasos-Ortygia, this highly mobile column must be regarded as having been made up entirely of his Hispani custodes corporis. Livy (25.25.1) describes the men manning the gates and walls of Achradina before their arrival as «chiefly deserters, who had no hope of pardon if terms were made», and they were in fact the very same deserters who, after the death of Epicydes, pushed for the choice of Moericus as praefectus of the hispani in Achradina (Livy, 25.30). The hispani of Epicydes and Moericus certainly regarded themselves as the guarantors of the defence of the city of Syracuse, and it is to them that the fourth issue of the second HISPANORVM series refers, given their role at the gates of Achradina during the weeks between Epicydes' leaving Ortygia and the fall of Syracuse. ${ }^{56}$

An epilogue to the history of the pro-Carthaginian hispani of Syracuse can most likely be traced back to the second issue of the first HISPANORVM series, which shows on the obverse a type of the laureate bust of Zeus Hellanios ( $\triangle \mathrm{IO}$

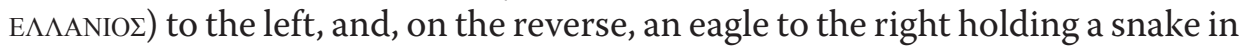
its claws [Fig. 16].$^{57}$ The extraordinary similarity in the style of the eagle on this HISPANORVM issue with the eagle in another bronze IYPAKOIISN coin (ungainly body, prominent chest, tail up) leaves little doubt that both issues were made

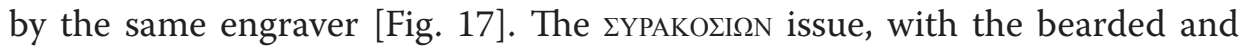
laureate head of Zeus to the right, not to mention its relative fine style, may be assigned to the year 212-210, when Rome was not yet in full control of the island. The pro-Carthaginian style of the HISPANORVM coin indicates an issue struck alongside the $\Sigma$ YPAKOIISN one, that is, minted since the middle of the year 212, when Epicydes was in Agrigentum after his escape from Syracuse and before his definitive flight to Africa (Livy 25.27.12). ${ }^{58}$ The eagles of the silver coins with a laureate head of Zeus to the right on the obverse, and a sea eagle standing in front with spread wings on a thunderbolt and the legend AKPAГANTIN $\Omega N$ on the reverse [Fig. 18], share notable similarities with the $\Sigma$ YPAKOEISN and HISPANORVM series, suggesting that all of these issues were in fact minted in Agrigentum..$^{59}$

56. Epicydes mounted attacks on Marcellus from Achradina, in conjunction with the forces of Hippocrates from outside Syracuse, (Livy 25.26.4), doubtless with the support of his hispani.

57. Erim, The «Hispanorvm» Coins, ix highlights about the eagle that «its action is a little uncertain».

58. Lazenby, Hannibal's War, 118.

59. Burnett, A., «The Enna Hoard and the silver coinage of the Syracusan. Democracy», RSN (Revue Suisse de Numismatique) 62, 1983, 5-26, for the chronology of these akragantine silver coin issues (213-211). 


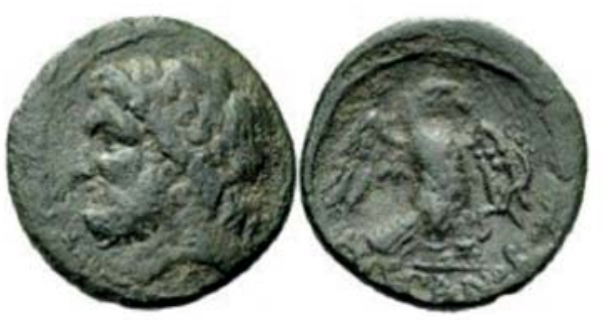

Fig. 16. Hispanorvm, Agrigentum, Bronze, Bronze, Amela Valverde, «La emisión HISPANORVM», 39, HGC 2917
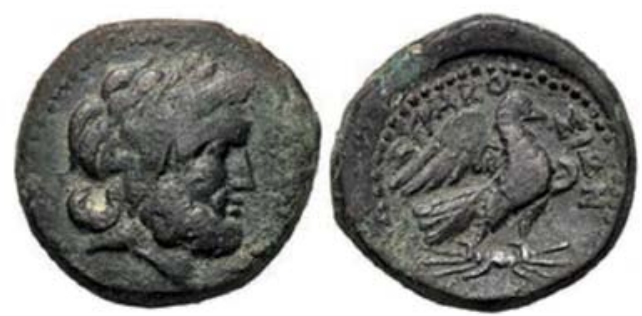

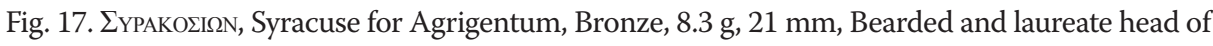
Zeus r./ eagle on thunderbolt r; Pecunem Gitbud \& Naumann, Auction 4, Lot number: 31

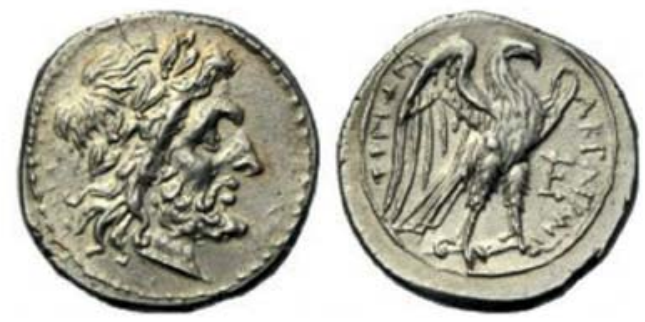

Fig. 18. AкPagantin $\Omega$, Akragas/ Agrigentum, silver, Drachm or Half Shekel, 211, 3.36 g, $18 \mathrm{~mm}$, Laureate head of Zeus r./ eagle standing l. with open wings on thunderbolt; at r., ArtCoins Roma s.r.l, Auction 6 (10.12.2012), Lot number 161

There are no coins labelled HISPANORVM with a typical Roman style from the Roman Agrigentum of the year 210, which may mean that the few hispani to accompany Epicydes as far as Agrigentum ${ }^{60}$ were not employed as garrison for Rome in this city. A large number of coins from the fifth issue of the third Hispanorvm series of Vico have, however, been found. ${ }^{61}$ On the obverse, this series depicts a bare male head to the right, with the legend C.SIC - L.IVNI, and on

60. To judge by the rarity of these issues from Agrigentum.

61. VICO BELMONTE, «Las monedas sicilianas», 355. 
the reverse a warrior galloping on a horse to the right, holding a spear [Fig. 19]. ${ }^{62}$ This issue, pro-Roman in both style and late chronology, was probably used not as coinage for veterans settled at Morgantina, but as payment for Marcellus' and Laevinus' new bodyguards during the years 211 and $210 .{ }^{63}$ Although Livy does not report in detail on the last stages of the war in Sicily, it is, however, clear from his narrative that the years 211 and 210 saw sustained action by Rome against Carthage around Agrigentum, the last important Carthaginian base on the island in 210 (Livy 26.40. 1). ${ }^{64}$ After Marcellus' departure to Rome for the consular elections at the end of the summer of 211 (Livy 26.21.1), ${ }^{65}$ and until the arrival of M. Valerius Laevinus in Sicily at the end of 210 (Livy 26.40.10), the Roman troops on the island - survivors of the great defeats at Cannae and Herdonea - were highly demoralised and ripe for sedition. ${ }^{66}$ For this reason it seems most unlikely that Rome should have demobilised the Hispanic troops that had joined their cause in Syracuse at the end of $212 .{ }^{67}$ The allocation of the town of Murgantia or Morgantina to the Hispanic troops by Marcus Cornelius in the year 211 could, in fact, be attributed not only to his defection in Syracuse. Livy's narrative does, though, encourage us to believe that the Hispanic troops, along with others such as Mamertine mercenaries, did play their part in maintaining control in the Sicilian cities which had seen uprisings (Livy 26.40.14). ${ }^{68}$ This circumstance provides an explanation why these coins have been found in reasonable numbers in central Sicily, especially at Morgantina, and it also explains the nature of the bust represented on the obverse of the fifth issues of the HISPANORVM series, probably a beardless, youthful Ares. The choice of this divinity might derive from the non-subjection to the magistrates of Syracuse, but also from the role of the hispani as a company in the service of particular leaders, in this case Marcellus and Laevinus. The sixth issue of the third HISPANORVM series, which depicts on the obverse a laureate head of Zeus Eleutherios to the right and on the reverse a Pegasus flying to the right (Fig 20)., should also be regarded as from the period after the fall of Syracuse (211-210). The representation of Pegasus on the reverse could perhaps be interpreted as a sign of the fractional nature of this issue, as well as of its connection with the horseman series. ${ }^{69}$

62. Amela Valverde, «La emisión hispanorvm», 40

63. In Livy, 26. 21.3-10, it is clear from the text that all Hispanics were under the personal protection of Marcellus, and thus guaranteed by the Senate and people of Rome. This personal relationship between Marcellus and the hispani proves that the former treated them in a similar way to that of Epicydes and Hippocrates, i.e. as his bodyguard.

64. Lazenby, Hannibal's War, 119, 172.

65. Ibidem, 120, 172.

66. «The Roman army (...) was serving without spirit. And what they lacked for a mutiny was a leader rather than the inclination», Livy, 25.5.10, 26.1.9-10.

67. The Numidians who defected to Rome in Sicily continued to fight well in 210, López SÁnCHEz, «Numidian Kings», 41.

68. LAzenby, Hannibal's War, 172.

69. It is very common in Graeco-Italian series that, on fractionary coins and where the size of the piece permitted it, the mounted horseman was replaced by a Pegasus, as a sign referring to «half» of the horseman. 


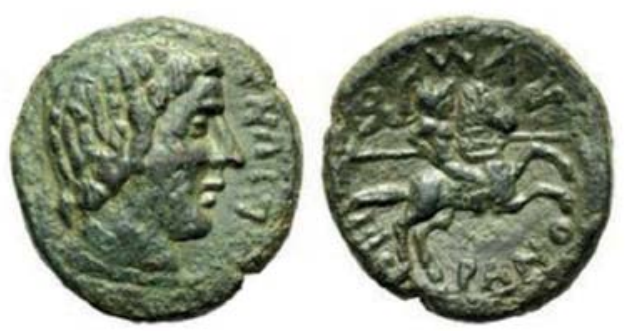

Fig. 19. Hispanorvm, Bronze, 211-210, $6.15 \mathrm{~g}, 19 \mathrm{~mm}$, bust of Ares r./warrior on horseback r., wearing helmet and holding spear, ArtCoins Roma, Auction 6, Auction date: 10 December 2012, Lot number: 197

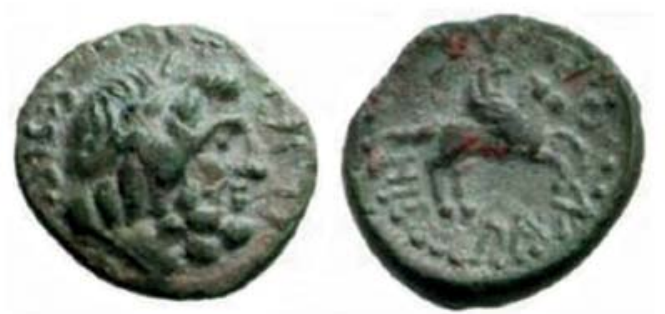

Fig. 20. Hispanorvm, Bronze, 211-210, 1.49 g. Laureate and bearded bust r/ Pegasus flying r.; Numismatica Ars Classica, Auction date: 12 May 2005, Lot number: 1200

CONCLUSIONS: THE HISPANORVM UNIT OF SPANIARdS AND Numidians Which BeCAME AN ELITE Unit IN SiCily

After the deaths of Hippocrates and Himilco and the flight of Epicydes to Africa in the summer of the year 212 (Livy, 25.26.7), ${ }^{70}$ the deserters and mercenaries of Syracuse suddenly found themselves without a leader ${ }^{71}$. Livy (25.29) recounts how the deserters pressured the mercenaries into another killing of magistrates and senators in Syracuse as well as the appointment of officers to replace their missing commanders. Livy states in this regard that «they (the mercenaries) chose six prefects, three to be in charge of Achradina and three of Nasus». Livy also notes that «one of the three prefects of Achradina was a Spaniard, Moericus by name» (25.30), thus making it clear that there were no other Hispanic prefects in Syracuse besides this one, an impression confirmed by the fact that land and a city to settle in were only offered to Moericus' men by Rome.

70. Lazenby, Hannibal's War, 117.

71. Ibidem, 119. 
The hispanorvm unit of the Spaniard Moericus did not necessarily have to be made up of individuals of the same Spanish nationality. On the occasion of the siege of Capua in the year 212, Livy relates how a cohort of hispani (cohors hispanorvm), with the support of three elephants, managed to cross the defensive ditch and the vallum of the Roman camp that was laying siege to the city, and enter it, causing panic (25.4.11). Livy's detailed narrative of the battle for Capua does, in fact, revolve around the struggle between this cohors hispanorvm ${ }^{72}$ and two Roman maniples of the sixth legion. ${ }^{73}$ On the four occasions that he mentions the hispani in action, Livy prefers to use terms such as cohors Hispanorvm (three times) or signa Hispanorvm (once), and on the one occasion when Livy refers to the hispani as individuals rather than as a military unit, they are associated with the Numidians («when Numidians and Spaniards with elephants had burst into the Roman camp unexpectedly»). ${ }^{74}$ The description of the cohors Hispanorvm by Livy thus turns out to be remarkably accurate. There can be little doubt that this military unit was a cohors equitata, that is, a blend of infantry and cavalry, ${ }^{75}$ made up of both Spaniards and Numidians. It may be assumed that all the Numidians were horsemen ${ }^{76}$ but it is also possible that some were Hispanic.

The hispanorvm unit of the Spaniard Moericus did not necessarily have to be made up of infantrymen as the cohors hispanorvm of Capua. The coexistence of Spaniards and Numidians in pro-Carthaginian units during the Second Punic War neither have to divide roles as it seem to have been occurred in this example from 212. In 214, when he was moving from Apulia to Mt Tifata, Hannibal was accompanied by Numidians and Spaniards whom he stationed at the latter location to defend the Carthaginian camp and the city of Capua (Livy, 24.12 1). All of them were very probably cavalrymen. A year earlier, in 215, 272 Numidian and Spanish horsemen at Nola defected en masse to join Marcellus (Livy, 24.45-47.11) and it is perhaps this last example, very close in its number to the 300 cavalrymen associated with a prafectus socium (or alae) in the Roman army, the best parallel that can be found to enable us to fully understand the hispanorvm unit commanded by Moericus. ${ }^{77}$ When

72. Livy claims not to believe the large numbers of Carthaginian and Campanian casualties attributed to this battle by some Roman sources, believing instead that «there was more panic than fighting» (LIVY 25.6.6). This source would be Valerius Antias.

73. The second maniple of the hastati, with Quintus Navius, and the first maniple of the principes of Marcus Atilius.

74. cum inopinato in castra Romana Numidae Hispanique cum elephantis inrupissent.

75. Livy describes the cohors hispanorvm as made up of horsemen as well as of infantry: «Hannibal likewise, seeing the slaughter of the Spanish cohort and that the enemy's camp was being defended with the utmost vigour, gave up the attack upon it and began to recall his standards and to make his infantry beat a retreat, while interposing his cavalry in the rear, to prevent the enemy from pursuing».

76. In the year 213, the Numidian king Syphax assured Publius and Gnaeus Scipio that «the Numidian nation was inexpert in infantry warfare, of service only as horsemen» (LIVY, 24.48.3).

77. Six praefecti socium are precisely the number of cavalry officers available to a Roman consular army at the end of the Third century, WALBAnK, A Historical Commentary I, 677; 300 Capuan knights were also serving in Sicily under Roman command, Livy 23.7.1-12; LAZEnby, Hannibal's War, 90. 
Livy relates the first military engagement of the auxiliary hispani of Epicydes and Hippocrates, he links them with the Numidians (Livy, 24.24 .1 in 214), though when he refers to the Hispanic unit commanded by Moericus in 212, no Numidians are mentioned. In this way, Livy seems to distinguish between a unit known as hispanorvm and the components of that unit, who were not solely Hispanic in origin ${ }^{78}$ but also Numidian. All of them seem in any case to have been mounted cavalrymen as they advanced «quickly» as a «moving column» from Nasos to Achradina with Epicydes in 212 (Livy, 25.24 8-10).

The army of the fifth democracy does not seem to have had more Hispanic units inside Syracuse in 212 than the one commanded by Moericus. ${ }^{79}$ However, it is possible that Epicydes and Hippocrates had each 300 mounted Spaniards and Numidians under their command, as they acted separately in various occasions. If this was the case, Moericus could have commanded late in 212 the remaining of a unit composed originally perhaps of up to 600 men. The hispanorvm unit of Epicydes and Hippocrates, can in any case clearly be identified with the HISPANORVM coin issues we have been dealing with in these pages. When they accompanied their commanders to Leontini or Agrigentum, or when they manned the garrison at Messana, the Spaniards and Numidians of the hispanorvm unit received coinage issued in their honour. Minted only in bronze and very probably of a fiduciary value, these coins were not, though, made by Hispanic engravers, but by others, Syracusans and PunoBruttians for the main part. The drive to produce coins did not, however, end with the fall of the fifth Republic, but was also made use of by Rome after the year 212. The positions held by the pro-Roman hispani (Spaniards and Numidians) were almost the same as those that were manned by pro-Carthaginian hispani before the year 212: Syracuse, Messana and Leontini, with the sole exception of Agrigentum. The significant production of HISPANORVM issues after the year 212, manufactured in a way that may be linked to Roman control in Syracuse, indicates thorough use of the unit for warlike purposes. In this context, the settlement of Sicilian hispani at Morgantina must be considered to have taken place in 210, only after the full pacification of Sicily.

78. In Livy, the term Hispania in the context of the Second Punic War seems to have been a strict equivalent of Celtiberia, as may be seen in book 35 of Polybius, Moret, P., «Sobre la polisemia de los nombres íber e Iberia en Polibio», Santos Yanguas, J. \& Torregaray E. (eds.), Polibio y la Península Ibérica, Vitoria-Gasteiz. Revisiones de Historia Antigua, IV, Universidad del País Vasco, 2003, 287; Livy (24.7-8) states that «more than three hundred hispani of the highest rank were sent to Italy to win over their fellow countrymen, who were among Hannibal's auxiliaries» (Livy, 24. 7-8). The Spaniard who convinced Moericus to defect to the Carthaginians, with the very Celtiberian name of Belligenes, seems to have been just such an individual.

79. Rawlings, L., «Celts, Spaniards and Samnites: warriors in a soldier's war», in CorNeLL ET ALII, The Second Punic War, 91 states that Celtiberians are certainly found on Carthaginian armies at the very end of the War, (i. e. the battle of the Great Plains in 203, Livy, 30.8), but Celtiberians or hispani were not recruited in a massive scale by Hannibal after Cannae. 